\title{
Zoom in, zoom out: Geographic scale and multinational activity
}

\author{
Ram Mudambi ${ }^{1}$, Lee $\mathrm{Li}^{2}$, \\ Xufei $\mathrm{Ma}^{3}$, Shige Makino ${ }^{3}$, \\ Gongming Qian ${ }^{3}$ and \\ Ron Boschma ${ }^{4}$
}

\footnotetext{
${ }^{1}$ Department of Strategic Management, Alter Hall, Fox School of Business, Temple University, Philadelphia, PA 19122, USA; ${ }^{2}$ York University, Toronto, Canada; ${ }^{3}$ Chinese University of Hong Kong, Shatin, Hong Kong; ${ }^{4}$ Utrecht University, Utrecht, The Netherlands

Correspondence:

R Mudambi, Department of Strategic Management, Alter Hall, Fox School of Business, Temple University, Philadelphia, PA 19122, USA.

Tel: 1-215-204-1692;

Fax: 1-215-204-8029;

e-mail: ram.mudambi@temple.edu
}

\begin{abstract}
IB scholars have long studied the multinational enterprise (MNE) and now recognize that its ability to capture value stems from its control of bottleneck assets. In contrast, economic geographers and regional scientists have largely focused their attention on the locations within which economic and business systems operate. In this article, we draw on both these literatures. We emphasize that the MNE's integration of upstream and downstream strategic considerations to maximize its control of bottleneck assets implies an optimal geographic footprint. This optimal footprint is typically asymmetric, with a spatial scale that varies dramatically across the different activities of the value chain. Upstream innovation processes are likely to be based on highly local considerations like the availability of specialized resources and collocation advantages. In contrast, downstream sales and marketing processes are likely to driven by imperatives of high volume and global reach. Further, in the current fast clockspeed business environment, the location and nature of bottleneck assets are likely to change rapidly and unpredictably, making organizational flexibility a crucial MNE capability.

Journal of International Business Studies (2018) 49, 929-94I.

https://doi.org/ | 0.1057/s41267-018-0158-4
\end{abstract}

Keywords: economic geography; knowledge management; knowledge transfer and innovation in MNCs/MNEs

\section{INTRODUCTION}

By definition, the country is the primary geographic unit of analysis within the international business (IB) canon. From the roots of the discipline, its focus has been on how firms internalize the country-specific advantages (CSAs) that stem from institutional, resource and market characteristics of various nation states and pair them with their own capabilities or firm-specific advantages (FSAs) (Dunning, 1988, 1998; Hillemann \& Gestrin, 2016), i.e., on the "attempts by firms to combine the comparative advantages of geographic locations with their own resources and competencies to maximize their competitive advantage" (Mudambi \& Venzin, 2010: 1511). While country borders remain discontinuities in geographic space, i.e., points where institutions, regulations, laws and even culture change abruptly (Beugelsdijk \& Mudambi, 2013), recent decades have witnessed political and policy changes like the Schengen Agreement that have ameliorated border effects in some parts of the world.
Received: 6 December 2017

Revised: 26 February 2018

Accepted: 14 April 2018

Online publication date: 5 June 2018 
Over the last decade, IB researchers have begun to recognize the weakness of using country borders as the sole unit to define location advantage. One of the first major attempts to address this challenge was the 2013 JIBS special issue that focused on the role of variations in the subnational geographic context on IB research (Beugelsdijk \& Mudambi, 2013). This challenge raises a host of new questions. For example, in addition to national and subnational contexts, do spatial variations in other geographic contexts also matter? How do the spatial variations at different geographic scales interact to influence the performance of multinational enterprises (MNEs)?

As emphasized in this special issue and several related contributions (e.g., Cantwell \& Iammarino, 1998; Iammarino \& McCann, 2013; Meyer, Mudambi, \& Narula, 2011), the introduction of other geographic scales does not replace the country as the primary geographic unit of analysis in IB. These analyses complement rather than substitute those based on country borders. They also sharpen location questions in both IB strategy and IB policy. In general, these analyses are likely to identify stronger and more significant effects in the case of large countries than smaller ones. This is because large countries ceteris paribus have a greater degree of subnational heterogeneity than small ones, as documented in the economics and political science literatures (e.g., Alesina \& Spolaore, 2005). Thus, while MNEs' downstream sales and marketing decisions regarding large nation states like the USA or China may be made at the country level, similar decisions in Europe may be made at the level of the European Union (EU). Further, their location decisions relating to upstream activities like research, design, and development are typically made at much smaller geographic scales, e.g., specific geographic hotspots like Silicon Valley, Shanghai or Stuttgart. This reasoning demonstrates that subnational, national and supranational contexts complement rather than substitute for one another.

The current special issue aims to advance the research agenda of integrating other spatial scales with the traditional IB geographic unit of the country. It serves as a follow-up to the JIBS 2013 special issue. In recent years, two streams of IB research have emerged to identify different levels of geographic scales in defining MNEs' location advantage. One stream has begun to zoom in and use finer geographic units, i.e., city- or provincebased clusters (intra-national regions), to examine MNEs' location advantage (Beugelsdijk, McCann, \&
Mudambi, 2010; Chan, Makino, \& Isobe, 2010; Goerzen, Asmussen, \& Nielsen, 2013; Ma, Tong, \& Fitza, 2013; Porter, 1994, 1998). In the second stream, researchers zoom out, coining the term "regionalization" (Rugman \& Verbeke, 2004; Rugman 2005) to argue that MNEs use supranational regions, like the European Union (EU) and NAFTA, rather than individual countries to define the primary geographic scope of their businesses (Qian, Li, Li, \& Qian, 2008; Qian, Li, \& Rugman, 2013; Rugman \& Verbeke, 2007). These new advances in IB also echo findings from international economic geography, which suggest that a simple home-host country dichotomy is no longer sufficient to capture the complexity of international production, trade and especially of innovation (Fujita, Krugman, \& Venables, 1999; Iammarino \& McCann, 2013; Meyer, et al., 2011).

In this overview paper, we advance IB theory by braiding these two literature streams together. We suggest that while both streams capture reality, it is necessary to integrate them in order to obtain a complete picture of the current global economy. We combine the two by arguing that the "zooming in" perspective into smaller geographic scales is necessary to understand upstream, knowledge-creation processes, based on the global value chain framework (Gereffi, Humphrey \& Sturgeon, 2005). In contrast, the "zooming out" perspective helps us to understand downstream market processes (Rugman \& Verbeke, 2004). This analysis enables us to view the MNE's overall orchestration of its GVC as the product of strategies that amalgamate subnational, national and supranational spatial scales. Complementing traditional country-level analysis, this research program presents IB scholars with a rich array of research questions.

\section{SPATIAL VARIATION OF LOCATION ADVANTAGE AT SUBNATIONAL, NATIONAL AND REGIONAL LEVEL}

The analysis of space in the context of commercial activity has concerned scholars since the early nineteenth century. The economic geography and regional studies literatures mainly focused on the local context of business and commerce, while international trade theory mainly concerned itself with the global context. Beginning with the von Thunen "bulls-eye" (1826), economic geographers developed sophisticated models of local systems. Along parallel lines, building on the foundations of the Smith-Ricardo model (Ricardo, 1817), 
international economists analyzed the global economy as a system that largely dealt with trade at the two ends of the value of chain: raw materials and final goods.

These complementary literatures dovetailed with one another for nearly a century and a half, with production occurring within local systems and trade within regional and global ones. Through the 1960s, the operations of even very large MNEs mostly conformed to this complementarity: They served national markets either through local production systems (e.g., the well-known miniature replica model, White \& Poynter, 1984) or exports of final goods. Indeed, this reality was so pervasive for so long that the assumptions that production systems were local and trade was global, became "stylized facts" and were rarely stated explicitly. The rise of intra-industry trade and trade in intermediate goods in the 1970s (Markusen, 1989), finally caused scholars to recognize that both the production and trading systems of MNEs were increasingly international. This insight appeared most powerfully in the classic work of Buckley and Casson (1976), who for the first time defined an MNE as a firm that internalized transactions across national borders, i.e., international, intra-firm activities.

Since 1980s, the IB literature has acknowledged that MNEs' performance is significantly influenced by the conditions that prevail in their environments (Bartlett \& Ghoshal, 1986; Porter, 1994, 1998). However, during 1980s and 1990s, the mainstream IB literature persisted in using the country as the geographic unit to analyze MNEs' location-based benefits and costs (i.e., countryspecific advantages or CSAs) and viewing spatial variation in terms of distance between countries (Qian, et al., 2008). In recent years, some IB scholars have begun to point out that such country border-based analysis may contain systematic biases and that important benefits and costs may be overlooked. These analyses attribute all spatial variation to country border effects and treat the subnational context as homogeneous (Ma et al., 2013; Qian et al., 2013). In practice, there are contexts where variation across national borders is suppressed so that the regional or supranational context becomes more important (e.g., the European Union) and others where the subnational context is quite heterogeneous (e.g., Quebec within Canada).

MNEs use FDI to achieve two strategic intents: (1) internalize missing or imperfect external markets until the costs of further internalization outweigh the benefits; and (2) choose locations for their constituent activities that minimize the overall costs of their operations (Buckley \& Casson, 1976). Spatial variation of location advantage at subnational, national and regional level all influence how these two intents are realized. The view that spatial scale, i.e., the subnational, national and supranational (or regional) levels of analysis, affects the benefits and costs of international operation has important implications for international business theory. In the following sections, we point to the impact of incorporating spatial scale on some well-known IB theories.

The three dimensions of the OLI paradigm ownership, location and internalization - are all impacted by spatial scale. In many cases, these effects can be fundamental and have become more important as global value chains have gained primacy. For instance, ownership advantages are significantly altered by subnational locational factors like special economic zones (SEZs), where foreign ownership generates privileges that are not extended to local firms (Jayanthakumaran, 2003). There is evidence that these SEZs create net increases in foreign direct investment (FDI), (rather than merely diverting it from other subnational locations). Further, this increased FDI within SEZs appears to stimulate rather than crowd out domestic investment (Wang, 2013). Similarly, "the role of sub-national spatial units as repositories for mobile investment" is highlighted in the famous awardwinning paper on the location dimension of the OLI paradigm (Dunning, 1998: 52).

A crucial theoretical lens within the IB literature has been the decomposition of MNE advantages into firm specific and country specific, i.e., the CSAFSA matrix (Rugman, 1981). There have been recent and highly sophisticated attempts that broaden the nature of CSAs (Hillemann \& Gestrin, 2016), but even these updated versions contain the unstated assumption of that the location advantages of the MNE flow from a given (national) spatial scale. However, the regional strategy perspective suggests that the locational advantage of MNEs may also arise at the supranational (regional) rather than simply the national scale (Rugman \& Verbeke, 2004; Rugman 2005; Verbeke \& Asmussen, 2016).

The IB literature's dichotomous approach to location appears most strongly in the concept "liability of foreignness," often reduced to the acronym LOF (Zaheer, 1995). At root, LOF is an 
insider-outsider dichotomy and this aspect has been much refined since the publication of the seminal paper. For instance, a key source of insidership seems to stem from a firm's characteristic of being a leader rather than a laggard, i.e., foreign (MNE) leaders may become insiders while domestic laggards remain outsiders (Cantwell \& Mudambi, 2011). However, spatial scale may also affect LOF, and these effects have received relatively little attention in the academic literature. Countries with significant cultural diversity like India often witness LOF effects at the subnational scale (Beugelsdijk \& Mudambi, 2013). LOF effects have also been established at the supranational (regional) scale (Qian et al., 2013).

The Uppsala internationalization process model is a staple of the IB literature that has stood the test of time (Johanson \& Vahlne, 1977). Not surprisingly, the model was originally articulated at the country level. However, in recent updates, the authors recognize that the original model's association with the concept of LOF is a limitation; they recommend incorporating a more general insider/ outsider taxonomy (Johanson \& Vahlne, 2009). As noted above, this allows for subnational and supranational spatial scales to affect the internationalization process.

\section{GLOBAL VALUE CHAIN (GVC) ANALYSIS}

Since the turn of the twenty-first century, the value creating activities of MNEs have been dispersed to such an extent that they can truly be characterized as global value chains (Gereffi, 1999; Mudambi \& Puck, 2016). GVCs have been documented in industries of all technology levels ranging from shoes (Pyndt \& Pedersen, 2006) and apparel (Smakman, 2003) to commercial aircraft (Kotha \& Srikanth, 2013). They are orchestrated by high knowledge MNEs that parcel out specialized activities to others within their ecosystem (Cano-Kollman, Cantwell, Hannigan, Mudambi \& Song, 2016). The two strategic nexuses of MNEs - location and control - effectively became equivalent to their GVC orchestration capabilities (Mudambi, 2008).

The GVC approach is exemplified by Gereffi, Humphrey and Sturgeon (2005) who identify three sets of variables that determine GVC governance: (1) the complexity of transactions, (2) the ability to codify transactions and (3) the capabilities in the supply base. While GVC scholars claim that governance is a major concern, their analyses of this aspect have been criticized for failing to incorporate the insights of modern organizational economics. In particular, this work often underestimates the effects of bounded rationality and bounded reliability on the decision-making processes within the orchestrating MNE (Verbeke \& Greidanus, 2009). Further, this work focuses on the upstream supply/ production side of the GVC. We extend this model, arguing that a complete specification requires adding in the downstream demand/marketing side.

The GVC literature, that has mainly emanated from the disciplines of geography and regional studies, has focused much more on the upstream supply/production side, but has paid relatively little attention to the organization of the MNEs that populate these ecosystems. In contrast, the organization of the MNE has been the main focus of the traditional IB literature. However, neither of these literatures has explicitly considered the question of spatial scale. Integrating the GVC and IB literatures presents a more complete picture of the organization of international business, but in order to do so, we argue that it is necessary to incorporate the concept of spatial scale.

\section{PLACE, SPACE AND ORGANIZATION}

Traditionally, the IB literature mainly used cultural, institutional, political and economic dimensions to assess relative advantages and measure distance (e.g., Ghemawat, 2003). Recently, there have been interdisciplinary efforts to integrate IB, economic geography and regional science to examine MNEs' activities in different locations along the dimensions of place, space and organization (Beugelsdijk, McCann, \& Mudambi, 2010; Beugelsdijk \& Mudambi, 2013; McCann \& Mudambi, 2004; 2005; Scalera, Perri, \& Hannigan, 2018, this special issue). Place refers to the geographic unit of analysis that includes the subnational, national and regional levels. Space refers to any characteristics that generate variation and heterogeneity among places (Beugelsdijk, McCann, \& Mudambi, 2010). Both "place" and "space" are required to determine the benefits and costs associated with the MNE's geographic footprint (Rugman, Verbeke, \& Yuan, 2011). The conceptualization and operationalization of the "place," "space" and "organization" dimensions have a strong theoretical grounding in the OLI paradigm (see, especially, Dunning, 1998).

Integrating IB and economic geography provides opportunities to develop a more holistic understanding of MNEs' geographically dispersed advantages and disadvantages (Beugelsdijk \& Mudambi, 
2013). The concept of place defines spatial discontinuities at three levels, i.e., subnational, national and regional levels, and thus enables MNEs to determine spatial heterogeneity and the consequent organization-level (dis) advantages in a finer way. Such spatial heterogeneity can be cultural, institutional, political or economic. On the other hand, the concept of place also helps MNEs to define spatial homogeneity within a particular geographic boundary, including the subnational, national or regional level. Again, such spatial homogeneity can be cultural, institutional, political or economic.

\section{A GLOBAL VALUE CHAIN MODEL OF SPATIAL VARIATIONS}

In the introduction to the JIBS (2013) special issue, it was suggested that "in order to advance the IB research agenda, it is critical to incorporate the relevant aspects of within-country variation and integrate these with those of between-country variation" (Beugelsdijk and Mudambi, 2013: 414). The current special issue goes a step further to add within-region and between-region variation and extend an MNE's location and its linkages across a wider space. We believe that incorporating heterogeneity as well as homogeneity at the subnational, national and supranational (regional) levels into the theory of the MNE improves our knowledge of MNEs as "enterprises in space" (Casson 1987: 1). The various spatial scales give rise to both cost and capability factors, and these have propelled the rise of GVCs.

\section{Spatial transaction costs}

Spatial transaction costs are the costs of undertaking transactions across space; transport and logistics costs are the most studied components. These latter costs have long been modeled using the iceberg model (Samuelson, 1954; McCann, 2005) wherein they increase monotonically with distance. The iceberg model relates transport costs linearly with distance, and assumes that these costs are paid out of the arriving volume. ${ }^{1}$ Improving transport and communication technologies have resulted in a steady decline in the iceberg transport costs since the beginning of the industrial revolution (Cuervo-Cazurra, Mudambi \& Pedersen, 2017). In the literature (especially in international economics), spatial transaction costs have often been assumed to be roughly proportional to iceberg costs (McCann, 2005).
There are two aspects of spatial transaction costs that are relevant to our current discussion. First, improving technologies have not only reduced the level of iceberg costs, but have also consistently reduced the slope of the distance-iceberg cost relationship. $^{2}$ This means that the distance-based cost disadvantage of far-flung locations has declined. Second, spatial transaction costs include both pure iceberg costs as well as other costs (including the portion of transport costs that are not affected by distance) arising from transacting across space. These costs arise from institutional differences and consist of items like drawing up and monitoring contracts across institutional and cultural boundaries, protecting valuable commercial knowledge in regimes where intellectual property rights are not as well developed as in the home country, and so on. Unlike iceberg costs that change smoothly and continuously with distance, the institutional components of spatial transaction costs are associated with "unfamiliarity" (Huang, 2007) jump discontinuously at national borders (Beugelsdijk and Mudambi, 2013). Further, they are much less amenable to technological solutions. Therefore, their decline has been much less precipitous than that of pure iceberg costs. Integrating these two aspects implies that the non-iceberg component of spatial transaction costs is now a much greater component than previously. In fact, in many instances, spatial decisions are entirely driven by institution-based costs.

In the case of knowledge assets like audio, visual and video entertainment, literature, codified information, and anything that can be reduced to an electronic form, iceberg transport costs are now virtually zero and institutional costs form the totality of spatial transaction costs. While spatial transaction costs are no longer proportional to iceberg transportation costs, they have nonetheless declined dramatically. In several settings, like the intra-MNE context, the spatial transaction costs of knowledge assets are much less important than the capabilities they engender.

Innovation capabilities: The integration of diverse locally rooted knowledge bases

While the transmission of codified knowledge is increasingly cheap, knowledge search and sourcing remains locally sticky (Jaffe, Trajtenberg \& Henderson, 1993; Markusen, 1996) and deep-rooted (Hannigan, Cano-Kollmann \& Mudambi 2015). Further, with the rise of emerging markets, the number of geographic locations participating meaningfully in 
global innovation systems is rising (Awate \& Mudambi, 2018). New knowledge is the key element in MNEs' innovation processes.

The wide global dispersal of knowledge hotspots coupled with the necessity of leveraging locally rooted knowledge, led MNEs to disaggregate their innovation activities over geographic space. In other words, the demands of innovation increasingly drive the location of MNE upstream knowledge creating activities. However, MNEs' global competitive advantage stems from their ability to generate capabilities by integrating diverse knowledge bases. Thus, MNEs' corporate innovation systems link local knowledge sourcing with global knowledge integration. In order to do so, the MNE must address the twin problems of technological diversity and geographic dispersal to generate cospecialized assets in local contexts (Teece, 1986; Schotter, Mudambi, Doz \& Gaur, 2017). Further, capturing value from innovation requires the MNE to retain control over the "bottleneck" assets within their global innovation systems (Teece, 1998).

This leads to the recognition that locational innovation advantage is based on both local resources and global linkages (Bathelt, Malmberg, $\&$ Maskell, 2004). The two aspects of "location" and "linkage" are both crucial. The key insight is that as far as location is concerned, the focus of MNEs' innovation systems is on narrow, very local geographic metro areas, the hotspots or so-called "spikes" on the global knowledge map (Huggins, 2008). The map of interconnected knowledge hotspots forms a global innovation network that is largely specific to each industry.

Hence, firms do not look for IT personnel in India, but look in Bangalore (Lorenzen and Mudambi, 2013). They do not locate in the USA, and they choose to locate in specific clusters. Empirical evidence demonstrates that automotive firms tend to locate their R\&D operations in Detroit (Hannigan et al., 2015), IT firms locate such knowledge-intensive activities in Silicon Valley and Boston (Saxenian, 1996), while biotech firms choose Boston, San Francisco and San Diego (Audretsch and Stephan, 1996; Coombs, Deeds, \& Mudambi, 2006).

Thus, the spatial scale of knowledge sourcing is extremely local, whereas spatial scale of knowledge integration is global. Teece's $(1986,1998)$ insights imply that in order to extract value from this complex process of search and integration, the
MNE must control bottleneck assets. In a world of fast clockspeed, the nature and location of these bottleneck assets are constantly changing, necessitating (often rapid) changes in the MNE's geographic locus. Hence, organizational flexibility emerges as a crucial capability of the modern MNE (Teece, 2014). This process of rapid rationalization incorporates both entry and divestment decisions. MNE entry decisions are the subject of a large literature in $\mathrm{IB}$, and while divestment has received much less attention, there is a relatively small stream of research here as well (e.g., Benito, 2005). However, we know very little about MNE activity rationalization incorporating the effects of spatial scale.

\section{Marketing capabilities: Global markets and MNE strategy}

In contrast to innovation where success is the outcome of interconnected, locally rooted small teams, success in global sales and markets often depends on large geographic scale. MNEs' focus at the downstream end of the value chain must be broad based in order to generate topline sales growth as well as bottom-line profit growth. The objective of knowledge-based innovation is the creation of products and services with the widest possible acceptance. The marketing function realizes its goals by monetizing innovative value propositions, i.e., by turning innovation into profits (Teece, 1986; Mudambi, 1998).

For downstream marketing objectives, the national context is usually very important, because tastes and preferences tend to be defined at this level. Thus, local customization of the value proposition is often done to address national particularities. For bigger firms, the regional context becomes important. Rugman and Verbeke (2004) demonstrate that most of the large Fortune Global 500 MNEs are regional in terms of sales data.

MNEs zoom out to look for markets, and they zoom in to look for knowledge. This can be related to the two key Dunning strategic imperatives market seeking is driven by zooming out, whereas asset seeking is focused on zooming in. This is illustrated in Figures $1 \mathrm{a}$ and $\mathrm{b}$, using the example of Nike, whose global value chain configuration is shaped like a trumpet. The geographic dispersion of Nike's output looks very different from the dispersion of its inputs and factories (Mudambi \& Puck, 2016). Similarly, automobile firms' value chains 

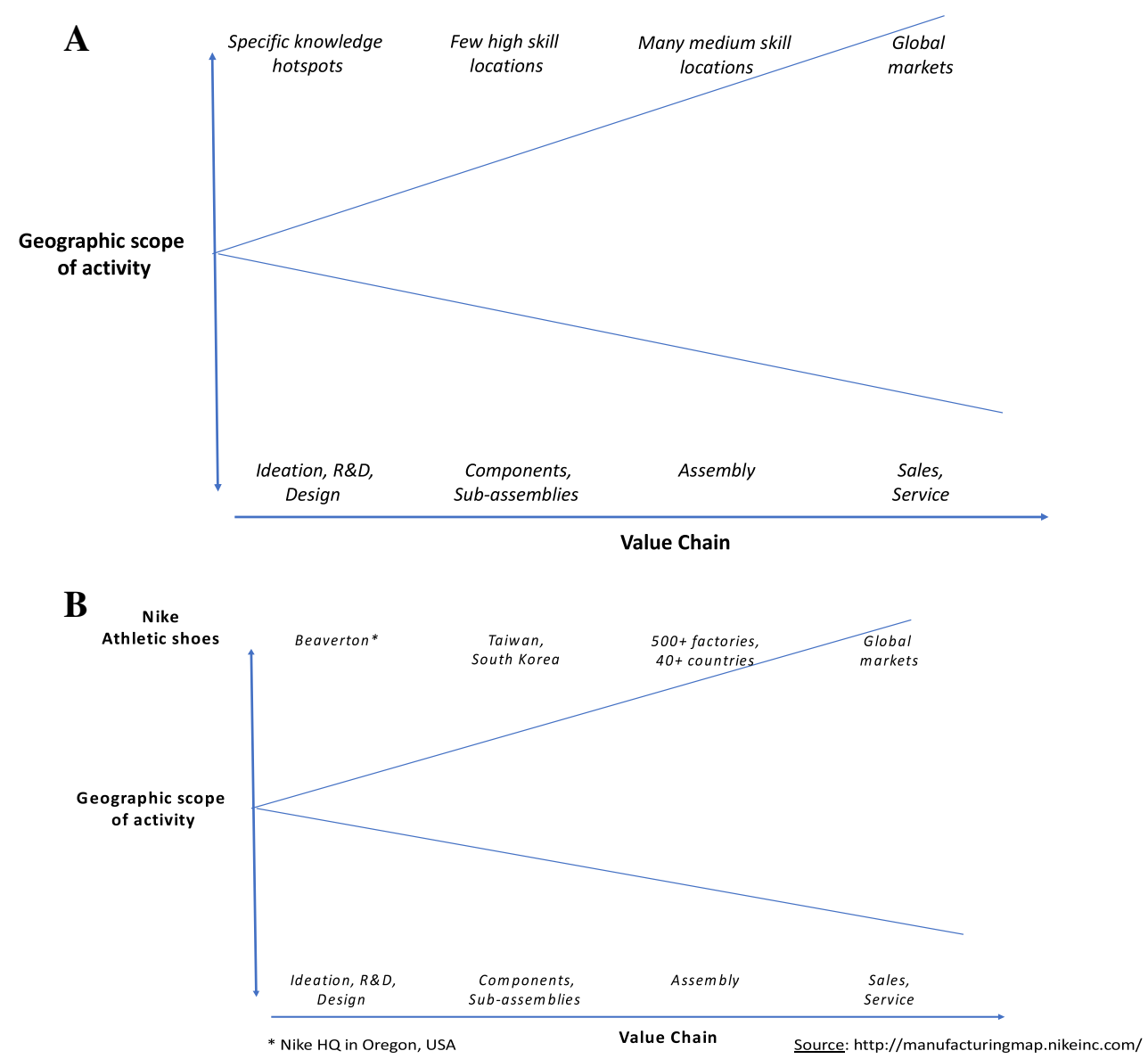

Figure 1 Localized knowledge hotspots service global markets

conform to this "trumpet configuration": Their innovation activities are concentrated in very specific hotspots of automotive knowledge like Detroit, Stuttgart, Munich, Yokohama and Nagoya (Hannigan et al., 2015), while their manufacturing plants are more numerous and service their widely distributed global sales.

However, as pointed out by Rugman, Verbeke and Yuan (2011), the footprint is also crucially dependent on MNE strategy. They provide a strategic taxonomy demonstrating that the extent of geographic dispersion of MNE activities is likely to vary from firm to firm (even within the same industry), dependent on their resources, capabilities and business realities. For instance, business to business MNEs typically have far fewer and more specialized customers and therefore much less geographic dispersion in their final sales than business to consumer MNEs. Whatever the optimal configuration, this value chain model provides a basis for understanding why the MNE's geographic footprint is very asymmetric and looks very different depending which function one is examining.

\section{THE WAY FORWARD: SPATIAL SCALES}

Till relatively recently, economic geographers and regional studies scholars largely treated cities and regions generally, as independent economic and business systems (e.g., Storper, 1995). This approach is also evident in Porter's (1998) analysis of clusters that is less geographic in its approach. Scholars in international economics examined linkages between locations almost entirely in terms of trade flows driven by location characteristics (e.g., Helpman and Krugman, 1989). The IB literature was more sophisticated in terms of recognizing the global linkages among locations operationalized through the operations of MNEs (Dunning and Lundan, 2008; Verbeke, van Tulder \& Lundan, 
2014), but the role of the systemic characteristics of locations was largely absent. Our "zoom in, zoom out" framework fills in the gap. It integrates the different layers of geographic space into a system of place by dropping the implicit assumption in the traditional IB literature that the country borders define MNEs' location advantages. Our framework raises intriguing questions and avenues for further research in both directions: zooming into local levels to source knowledge and zooming out to pursue markets.

In terms of zooming in, recent research on the local innovation systems suggests that the role of spatial scales may be more complex than previously thought (Boschma, 2005). Local systems were traditionally bounded by commuting radii (Berry, 1960; Preston \& McLafferty, 1999), typically set at about 30 miles (Schnore, 1954). Traditional approaches to proximity in economic geography used this measure of commuting radius to define local spatial scale (Cervero \& Wu, 1997). Much of the early work of local innovation followed this lead (Jaffe et al., 1993). However, a novel and important research approach is the discovery of significant location effects at extremely small spatial scales. This approach has been termed microgeography (Feldman 2014).

The microgeography approach emphasizes the importance of "zooming in" to a much smaller scale to get a true picture of locational advantage. In other words, the beating heart of knowledge and innovation systems that generate the location advantage of city regions, or even nations, can sometimes be traced to very small neighborhoods. These may be based on co-ethnic ties (Stallkamp, Pinkham, Schotter, \& Buchel, 2018, current issue) or idiosyncratic ties based on office location within buildings (Catalini 2018). This research stream suggests that innovation and associated business activities may be extremely fragile and easily upset by policy and organizational shocks. It highlights the importance of extremely fine-grained analyses to understand the key linchpins of local systems some of which may be global, and others which may be local at such a minute spatial scale that it has thus far escaped notice.

IB researchers have long recognized that distance metrics other than the pure geographic one may be more important. Regarding zooming out, regions that are geographically distant, but share common institutions and language, may form common target markets. It has been documented that the widely dispersed countries of the British
Commonwealth share higher cross-border trade than would have been predicted by pure economic factors (Lundan and Jones, 2001). Firms from the Maghreb typically internationalize sales first to France rather than geographically neighboring countries (Cuervo-Cazurra, 2011). Spanish MNEs have rapidly expanded FDI and sales in geographically distant, but linguistically and culturally proximate Latin America (Cuervo-Cazurra, 2016; Guillen, 2005; Toral, 2008). Such geographically distant but culturally proximate regions should be used to define markets in the future studies.

The recognition that locational advantage is based on both internal resources as well as global linkages is beginning to move to the mainstream (Bathelt, Malmberg and Maskell, 2004). These global linkages are of two generic types - MNEdriven "pipelines" and individually motivated "personal relationships" (Lorenzen and Mudambi, 2013). Future research must be predicated not on the evolution or firms or locations, but rather on the coevolution of firms and locations (Cantwell, Dunning, and Lundan 2010). They are bound together in what has been called the "flowers and bees" model, wherein mobile MNEs and immobile locations are codependent parts of a global system (Cano-Kollman et al., 2016). These coevolutionary processes zoom into the local level as MNEs generate upstream R\&D-based knowledge. They zoom out to the national, regional and sometimes global level as these firms leverage downstream marketing knowledge.

\section{A FRESH START}

Collectively, the seven papers included in this special issue offer an excellent reflection of the model we have developed above. The first paper, by Stallkamp, Pinkham, Schotter, and Buchel (2018), relaxes the assumptions of predefined administrative boundaries to look more deeply into the discontinuities, irregularities and heterogeneity of the spatial evolution of MNEs over time. This study extends the core-periphery framework and integrates it with the co-ethnic perspective grounded in economic sociology, demonstrating that MNEs zoom in their high knowledge activities within co-ethnic agglomerations within narrowly defined city neighborhoods, rather than the administrative boundaries in the host country. Further, these coethnic ties also influence within-country expansion. With the help of geo-visualization techniques from geographic information science (GIS), it 
provides a much more nuanced understanding of the within-host-country expansion of Japanese MNEs in China.

The second paper, by $\mathrm{Li}$ and Bathelt (2018), establishes and analyzes a database of 3,500 investment cases within and between Canada and China to investigate the location strategies of multisite firms in investment decisions at the metropolitan level. By integrating research from IB studies and economic geography, they combine a knowledgebased understanding of MNEs and industrial clusters. Clearly, as firms in the context of this study source knowledge rather than seek markets, they tend to adopt the zoom-in approach to the cluster level. Interestingly, the analysis reveals that the home cluster effect is much more important than the home country effect in directing investments to cluster locations. This finding suggests that previous investigations in IB studies may overestimate the country-of-origin effect by not zooming into the scale of the city or the cluster.

The third paper, by Scalera, Perri and Hannigan (2018) proposes a theoretical framework that distinguishes between discrete discontinuities across national contexts and continuous subnational differences, i.e., distance versus border effects. It combines the Penrosean view of managerial capabilities with the attention-based theory of the firm. By analyzing a sample of US-based firms between 1990 and 2006, this paper shows that both domestic and international knowledge connectedness affect the technological scope of firm innovations, but their effect is different. The framework and findings advance our understanding of innovation and knowledge sourcing by explicitly zooming in to the geographic space as characterized by both international and subnational heterogeneity.

In a context of international new ventures (INVs) from emerging markets, the fourth paper, by Deng, Jean \& Sinkovics (2018), examines the relationship between rapid export expansion across institutional distance and overall firm performance. Moreover, it incorporates directionality into export expansion in terms of the upward exporting to more open countries and the downward exporting to less open countries. Instrumental variable models based on data of Chinese indigenous INVs during 2000-2009 support the hypotheses. This study represents a systematic and empirical attempt to zoom out the analytical lens along the locationrelated institutional axis, examines the joint effect of institutions involved in supranational directions and subnational origins on firm performance and advances institutional theory.

The fifth paper, by Iurkov and Benito (2018), provides an alternative theoretical lens, which is the social network perspective, to explain the geographic scope of multinational enterprises (MNEs). Using the FDI data of US MNEs in the information and communication technology industry for the period 2001-2008, the authors focus on how the positioning of MNEs in their domestic network of strategic alliances affects their geographic scope. They further highlight the moderating role of the MNEs' organizational ability to efficiently and effectively absorb resources stemming from the network.

The sixth paper, by Gao, Wang, and Che (2018), brings historical conflict into the zooming behavior and performance of MNEs in a host country. In this study, using a sample of 8,646 instances of Japanese FDI in China, they show the civilian casualties in different provinces of China during the Second Sino-Japanese war exert deterring effects on Japanese FDI location choice and FDI performance. They further highlight how political capital accumulation strategies can mitigate the negative effects of historical conflicts. This study adds a new dimension (i.e., historical factors) to the discussion on within-country differences affecting MNEs' FDI location choice and performance.

The concluding paper in the special issue is a conceptual perspective paper by Peterson, Søndergaard and Kara (2017). The authors first consider functional, institutional and critical event explanations for cultural characteristics and boundaries; they then contrast theories of explicit global structure based on countries with theories based on implicit cultural groups; and they further consider the implications of explicit country-based and implicit culture group-based theorizing for the relationship between explicit country boundaries and implicit cultural group boundaries. This paper points to the importance of understanding the complex mix of correspondence and discontinuity between country and cultural group boundaries when issues of spatial scale are explored by IB scholars.

\section{CONCLUDING REMARKS}

It is widely recognized that in the modern knowledge economy, innovation is the key to wealth generation (King, 2004, Mudambi, 2008). Innovation is charac- 
terized by two fundamental empirical realities. First, the knowledge creation landscape is extremely spiky, with towering hotspots and vast flat plains featuring virtually no creative processes (Florida, 2005; Iriyama, Li, \& Madhavan, 2010; Kim \& Aguilera, 2015). Second, the pace of innovation has been rising inexorably; in today's economy, firms are born and reach global scale in a matter of months and industries arise, mature and decline in less than a decade (Brynjolfsson \& McAfee, 2011). The last few decades have been truly dubbed the "age of temporary advantage" (Fine, 1998).

The nexus of IB and economic geography offers a means of understanding the emerging knowledge economy of the twenty-first century. As we have argued here, the MNEs of the future must balance two strategic imperatives. On the one hand, they must continually create highly specialized capabilities that are based on knowledge resources that reside in very specific locations. On the other hand, they must deliver the product of these capabilities to global markets. Integrating the IB and economic geography perspectives yields a framework that encompasses both these fundamental priorities.

Our analysis raises crucial questions for future researchers. The first has to do with the control aspect of "zooming out." While the location of the dispersed activities that underpin the MNE's value creation is based on resource availability, the control dimension is less obvious (Mudambi \& Puck, 2016). The capabilities that support the successful orchestration of this complex and geographically scattered array are still not well understood, especially since they are continually changing (Mudambi, 2008; Teece, 2014). The second has to do with the geography of the "zooming in" process. Casual empirical observation demonstrates that some firms, like Apple and Nike, maintain highly centralized innovation systems concentrated around their headquarters (though this has been changing recently). Others, like IBM and Google, run multiple high-level $R \& D$ units dispersed around the world embedded in important knowledge hotspots (Hannigan \& Mudambi, 2015). In other words, in the subpopulation of highly successful firms, some pursue a strategy of centralization with regard to their knowledge creation processes whereas others pursue a strategy of dispersion. Further research is needed to understand this dichotomy - and whether it is changing.
Finally, as pace of technological advance increases, one of the most important attributes of survival and success is organizational flexibility (Teece, 2014). While the MNE's goals may remain constant, the activities that are incorporated in its value chain, as well as their location and their control structures, are all open to change. What this dynamic process means for the coevolution of MNEs and geographic locations is one of the most important future research agendas for social science scholars.

\section{NOTES}

${ }^{1}$ The model owes its historical origin to the nineteenth century trade in ice that was used for cooling purposes and the preservation and preparation of food, both by households and businesses. Boston was a center of the global trade and shipped ice to Brazil, China, India, the Philippines and Australia, among many other destinations. Exports peaked around 1860 at about 150,000 tons (Weightman, 2003). Prior to the ice trade, Boston's trade with the tropics was mainly one way: Ships sailed out in ballast and returned with cargoes of cotton, hemp, sugar and other tropical commodities (Dickason 1991: 64). Since ice replaced ballast, virtually the only cost was the ice melt in transit that was roughly proportional to distance traveled hence the term iceberg costs.

Von Thunen (1826) anticipated the iceberg model, by incorporating in-transit shrinkage of the shipped good into transport costs. He used the example of transporting grain to market, where part of the shipment was fed to the oxen pulling the cart.

${ }^{2}$ See McCann (2001) for a derivation of the reduced slope of the "freight curve" and its relationship to total logistics costs.

\section{REFERENCES}

Alesina, A. \& Spolaore, E. 2005. The size of nations. Cambridge MA: The MIT Press.

Audretsch, D., \& Stephan, P. 1996. Company-scientist locational links: The case of biotechnology. American Economic Review, 86(3): 641-653.

Awate, S., \& Mudambi, R. 2018. On the geography of emerging industry technology networks: The breadth and depth of patented innovations. Journal of Economic Geography, 18(2): 391-419. 
Bartlett, C., \& Ghoshal, S. 1986. Tap your subsidiaries for global reach. Harvard Business Review, 64, 87-94.

Bathelt, H., Malmberg, A., \& Maskell, P. 2004. Clusters and knowledge: Local buzz, global pipelines and the process of knowledge creation. Progress in Human Geography, 28(1): 31-56.

Benito, G. 2005. Divestment and international business strategy. Journal of Economic Geography, 5(2): 235-251.

Berry, B. 1960. The impact of expanding metropolitan communities upon the central place hierarchy. Annals of the American Association of Geographers, 50(2): 112-116.

Beugelsdijk, S., McCann, P., \& Mudambi, R. 2010. Place, space and organization: Economic geography and the multinational enterprise. Journal of Economic Geography, 10(4): 485-493.

Beugelsdijk, S., \& Mudambi, R. 2013. MNEs as border-crossing multi-location enterprises: The role of discontinuities in geographic space. Journal of International Business Studies, 44(5): 413-426.

Boschma, R. 2005. Proximity and innovation: a critical assessment. Regional Studies, 39(1): 61-74.

Brynjolfsson, E., \& McAfee, A. 2011. The race against the machine: How the digital revolution is accelerating innovation, driving productivity, and irreversibly transforming employment and the economy. New York: Digital Frontier Press.

Buckley, P. J., \& Casson, M. 1976. The future of the multinational enterprise. London: Macmillan.

Cano-Kollman, M., Cantwell, J. A., Hannigan, T. J., Mudambi, R., \& Song, J. 2016. Knowledge connectivity: An agenda for innovation research in international business. Journal of International Business Studies, 47(3): 255-262.

Cantwell, J., Dunning, J., \& Lundan, S. 2010. An evolutionary approach to understanding international business activity: The co-evolution of MNEs and the institutional environment. Journal of International Business Studies, 41(4): 567-586.

Cantwell, J., \& lammarino, S. 1998. MNCs, technological innovation and regional systems in the EU: Some evidence in the Italian case. International Journal of the Economics of Business, 5(3): 383-408.

Cantwell, J., \& Mudambi, R. 2011. Physical attraction and the geography of knowledge sourcing in multinational enterprises. Global Strategy Journal, 1(3-4): 206-232.

Casson, M. 1987. The firm and the market: Studies in multinational enterprises and the scope of the firm. Cambridge, MA: MIT Press.

Catalini, C. 2018. Microgeography and the direction of inventive activity. Management Science, forthcoming.. https://doi. org/10.1287/mnsc.2017.2798.

Cervero, R., \& Wu, K.-L. 1997. Polycentrism, commuting and residential location in the San Francisco Bay area. Environment and Planning A, 29(5): 865-886.

Chan, C. M., Makino, S., \& Isobe, T. 2010. Does subnational region matter? Foreign affiliate performance in the United States and China. Strategic Management Journal, 31(11): 1226-1243.

Coombs, J., Deeds, D., \& Mudambi, R. 2006. An examination of the investments in U.S. biotechnology firms by foreign and domestic corporate partners. Journal of Business Venturing, 21(4): 405-428.

Cuervo-Cazurra, A. 2011. Selecting the country in which to start internationalization: The non-sequential internationalization argument. Journal of World Business, 46(4): 426-437.

Cuervo-Cazurra, A. 2016. Multilatinas as sources of new research insights: the learning and escape drivers of international expansion. Journal of Business Research, 69(6): 1963-1972.

Cuervo-Cazurra, A., Mudambi, R., \& Pedersen, T. 2017. Globalization: rising skepticism. Global Strategy Journal, 7(2): 155-158.

Deng, Z., Jean, R., \& Sinkovics, R. 2018. Rapid export expansion of international new ventures from emerging economics: Location, supranational directionality, and subnational origin.
Journal of International Business Studies. https://doi.org/10. 1057/s41267-017-0108-6 (this special issue).

Dickason, D. G. 1991. The nineteenth-century Indo-American ice trade: An hyperborean epic. Modern Asian Studies, 25(1): 53-89.

Dunning, J. H. 1988. The eclectic paradigm of international production: A restatement and some possible extensions. Journal of International Business Studies, 19(1): 1-31.

Dunning, J. H. 1998. Location and the multinational firm: a neglected factor? Journal of International Business Studies, 29(10): 45-66.

Dunning, J. H., \& Lundan, S. 2008. Multinational enterprises and the global economy. Cheltenham: Edward Elgar.

Feldman, M. 2014. The character of innovative places: Entrepreneurial strategy, economic development and prosperity. Small Business Economics, 3(1): 9-20.

Fine, C. H. 1998. Clockspeed: Winning industry control in the age of temporary advantage. New York: Basic Books.

Florida, R. 2005. The world is spiky: Globalization has changed the economic playing field, but hasn't leveled it. The Atlantic Monthly, 296(3): 48-51.

Fujita, M., Krugman, P., \& Venables, T. 1999. The spatial economy: Cities, regions and international trade. Cambridge, MA: MIT Press.

Gao, G.Y., Wang, D.T., \& Che, Y. 2018. Impact of historical conflict on FDI location and performance: Japanese investment in China. Journal of International Business Studies. https:// doi.org/10.1057/s41267-016-0048-6 (this special issue).

Gereffi, G. 1999. International trade and industrial upgrading in the apparel commodity chain. Journal of International Economics, 48(1): 37-70.

Gereffi, G., Humphrey, J., \& Sturgeon, T. 2005. The governance of global value chains. Review of International Political Economy, 12(1): 78-104.

Ghemawat, P. 2003. Semi-globalization and international business strategy. Journal of International Business Studies, 34(2): 138-152.

Goerzen, A., Asmussen, C., \& Nielsen, B. 2013. Global cities and multinational enterprise location strategy. Journal of International Business Studies, 44(5): 427-450.

Guillen, M. 2005. The rise of Spanish multinationals: European business in the global economy. Cambridge and New York: Cambridge University Press.

Hannigan, T. J., Cano-Kollmann, M., \& Mudambi, R. 2015. Thriving innovation amidst manufacturing decline: The Detroit auto cluster and resilience of local knowledge production. Industrial and Corporate Change, 24(3): 613-634.

Hannigan, T.J. \& Mudambi, R. 2015. Local R\&D won't help you go global. Harvard Business Review online, June 25.

Helpman, E., \& Krugman, P. 1989. Trade policy and market structure. Cambridge MA: The MIT Press.

Hillemann, J., \& Gestrin, M. 2016. The limits of firm-level globalization: Revisiting the FSA/CSA matrix. International Business Review, 25(3): 767-775.

Huang, R. 2007. Distance and trade: Disentangling unfamiliarity effects and transport cost effects. European Economic Review, 51(1): 161-181.

Huggins, R. 2008. The evolution of knowledge clusters: Progress and policy. Economic Development Quarterly, 22(4): 277-289.

lammarino, S., \& McCann, P. 2013. Multinationals and economic geography: Location, technology and innovation. Cheltenham: Edward Elgar.

Iriyama, A., Li, Y., \& Madhavan, R. 2010. Spiky globalization of venture capital investments: The influence of prior human networks. Strategic Entrepreneurship Journal, 4(2): 128-145.

lurkov, V., \& Benito, G. 2018. Domestic alliance networks and regional strategies of MNEs: A structural embeddedness perspective. Journal of International Business Studies. https:// doi.org/10.1057/s41267-017-0089-5 (this special issue). 
Jaffe, A., Trajtenberg, M., \& Henderson, R. 1993. Geographic localization of knowledge spillovers as evidenced by patent citations. Quarterly Journal of Economics, 108(3): 577-598.

Jayanthakumaran, K. 2003. Benefit-cost appraisals of export processing zones: A survey of the literature. Development Policy Review, 21(1): 51-65.

Johanson, I., \& Vahlne, J. 1977. The internationalization process of the firm: A model of knowledge development and increasing foreign market commitments. Journal of International Business Studies, 8(1): 23-32.

Johanson, J., \& Vahlne, J. 2009. The Uppsala internationalization process model revisited: From liability of foreignness to liability of outsidership. Journal of International Business Studies, 40(9): 1411-1431.

Kim, J. U., \& Aguilera, R. V. 2015. The world is spiky: An internationalization framework for a semi-globalized world. Global Strategy Journal, 5(2): 113-132.

King, D. 2004. The scientific impact of nations. Nature, 430, $311-316$

Kotha, S., \& Srikanth, K. 2013. Managing a global partnership model: Lessons from the Boeing 787 'Dreamliner' program. Global Strategy Journal, 3(1): 41-66.

Li, P., \& Bathelt, H. 2018. Location strategy in cluster networks. Journal of International Business Studies. https://doi.org/10. 1057/s41267-017-0088-6 (this special issue).

Lorenzen, M., \& Mudambi, R. 2013. Clusters, connectivity and catch-up: Bollywood and Bangalore in the global economy. Journal of Economic Geography, 13(3): 501-534.

Lundan, S., \& Jones, G. 2001. The 'Commonwealth Effect' and the process of internationalization. The World Economy, 24(1): 99-118.

Ma, X., Tong, T. W., \& Fitza, M. 2013. How much does subnational region matter to foreign subsidiary performance? Evidence from Fortune Global 500 corporations' investment in China. Journal of International Business Studies, 44(1): 66-87.

Markusen I 1989. Trade in producer services and other specialized intermediate inputs. American Economic Review, 79(1): 85-95.

Markusen, A. 1996. Sticky places in slippery space: A typology of industrial districts. Economic Geography, 72(3): 293-313.

McCann, P. 2001. A proof of the relationship between optimal vehicle size, haulage length and the structure of distancetransport costs. Transportation Research A, 35, 671-693.

McCann, P. 2005. Transport costs and the new economic geography. Journal of Economic Geography, 5(3): 305-316.

McCann, P., \& Mudambi, R. 2004. The location decision of the multinational enterprise: Some theoretical and empirical issues. Growth \& Change, 35(4): 491-524.

McCann, P., \& Mudambi, R. 2005. Analytical differences in the economics of geography: The case of the multinational firm. Environment and Planning A, 37(10): 1857-1876.

Meyer, K., Mudambi, R., \& Narula, R. 2011. Multinational enterprises and local contexts: The opportunities and challenges of multiple-embeddedness. Journal of Management Studies, 48(2): 235-252.

Mudambi, R. 1998. International financial management: A review. Journal of Finance, 53(3): 1194-1197.

Mudambi, R. 2008. Location, control and innovation in knowledge-intensive industries. Journal of Economic Geography, 8(5): 699-725.

Mudambi, R., \& Puck, J. 2016. A global value chain analysis of the 'regional strategy' perspective. Journal of Management Studies, 53(6): 1076-1093.

Mudambi, R., \& Venzin, M. 2010. The strategic nexus of offshoring and outsourcing decisions. Journal of Management Studies, 47(8): 1510-1533.

Peterson, M., Søndergaard, M., \& Kara, A. 2017. Traversing cultural boundaries in IB: The complex relationships between explicit country and implicit cultural group boundaries at multiple levels. Journal of International Business Studies. https:// doi.org/10.1057/s41267-017-0082-z. (this special issue).
Porter, M. 1994. The role of location in competition. Journal of the Economics of Business, 1(1): 35-40.

Porter, M. 1998. Clusters and the new economics of competition. Harvard Business Review, 76(6): 77-90.

Preston, V., \& McLafferty, S. 1999. Spatial mismatch in the 1990s: Progress and potential. Papers in Regional Science, 78(4): 387-402.

Pyndt, J., \& Pedersen, T. 2006. Managing global offshoring strategies: A case approach. Copenhagen: Copenhagen Business School Press.

Qian, G., Li, L., Li, J., \& Qian, Z. 2008. Regional diversification and firm performance. Journal of International Business Studies, 39(2): 197-214.

Qian, G., Li, L., \& Rugman, A. M. 2013. Liability of country foreignness and liability of regional foreignness: Their effects on geographic diversification and firm performance. Journal of International Business Studies, 44(6): 635-647.

Ricardo, D. 1817. The principles of political economy and taxation. London: John Murray.

Rugman, A. 1981. Inside the multinationals: The economics of internal markets. New York: Columbia University Press.

Rugman, A. 2005. The regional multinationals: MNEs and 'global' strategic management. Cambridge, UK: Cambridge University Press.

Rugman, A., \& Verbeke, A. 2004. A perspective on the regional and global strategies of multinational enterprises. Journal of International Business Studies, 35(1): 3-18.

Rugman, A., Verbeke, A., \& Yuan, W. 2011. Re-conceptualizing Bartlett and Ghoshal's classification of subsidiary roles in the multinational enterprise. Journal of Management Studies, 48(2): 253-277.

Rugman, A., Verbeke, A., et al. 2007. Liabilities of regional foreignness and the use of firm-level versus country-level data: A response to Dunning, Journal of International Business Studies, 38(1): 200-205.

Samuelson, P. A. 1954. Transfer problem and the transport cost, II: Analysis of effects of trade impediments. Economic Journal, 64, 264-289.

Saxenian, A. 1996. Regional advantage: Culture and competition in Silicon Valley and Route 128. Boston: Harvard University Press.

Scalera, V., Perri, A., \& Hannigan, T. J. 2018. Knowledge connectedness within and across countries: Multi-level spatial heterogeneity and the technological scope of firm innovativeness. Journal of International Business Studies. https://doi.org/ 10.1057/s41267-017-0109-5 (this special issue).

Schnore, L. 1954. The separation of home and work: A problem for human ecology. Social Forces, 32(4): 336-343.

Schotter, A., Mudambi, R., Doz, Y., \& Gaur, A. 2017. Boundary spanning in global organizations. Journal of Management Studies, 54(4): 403-421.

Smakman, F. 2003. Local industry in global networks: Changing competitiveness, corporate strategies and pathways of development in Singapore and Malaysia's garment industry. Ph.D. dissertation, Utrecht University. The Netherlands: Rozenberg Publishers.

Stallkamp, M., Pinkham, B., Schotter, A. \& Buchel, O. 2018. Core or periphery? The effect of country-of-origin agglomerations on within-country expansions of MNEs. Journal of International Business Studies. https://doi.org/10.1057/ s41267-016-0060-x (this special issue).

Storper, M. 1995. The resurgence of regional economies, ten years later: The region as the nexus of untraded interdependencies. European Urban and Regional Studies, 2(3): 191-221.

Teece, D. 1986. Profiting from technological innovation: Implications for integration, collaboration, licensing and public policy. Research Policy, 15(6): 285-305.

Teece, D. 1998. Capturing value from knowledge assets: The new economy, markets for know-how and intangible assets. California Management Review, 40(3): 55-79. 
Teece, D. 2014. The foundations of enterprise performance: Dynamic and ordinary capabilities in an (economic) theory of firms. Academy of Management Perspectives, 28(4): 328-352.

Toral, P. 2008. The foreign direct investments of Spanish multinational enterprises in Latin America, 1989-2005. Journal of Latin American Studies, 40(3): 513-544.

Verbeke, A., \& Asmussen, C. 2016. Global, local or regional: The locus of MNE strategies. Journal of Management Studies, 53(6): 1051-1057.

Verbeke, A., \& Greidanus, N. 2009. The end of the opportunism vs. trust debate: Bounded reliability as a new envelope concept in research on MNE governance. Journal of International Business Studies, 40(9): 1471-1495.

Verbeke, A., van Tulder, R., \& Lundan, S. 2014. Multinational enterprises, markets and institutional diversity. London: Emerald Publishing.

von Thunen, J.H. 1826. The isolated state with respect to agriculture and political economy. Translated by Carla Wartenberg, 1966. Oxford: Pergamon Press.

Wang, J. 2013. The economic impact of Special Economic Zones: Evidence from Chinese municipalities. Journal of Development Economics, 101, 133-147.

Weightman, G. 2003. The frozen water trade: A true story. New York: Hyperion.

White, R., \& Poynter, T. 1984. Strategies for foreign-owned subsidiaries in Canada. Business Quarterly, 49(2): 59-69.

Zaheer, S. 1995. Overcoming the liability of foreignness. Academy of Management Journal, 38(2): 341-363.

\section{ABOUT THE AUTHORS}

Ram Mudambi is the Frank M. Speakman Professor of Strategy at the Fox School of Business, Temple University. His research focuses on the geography of innovation. His work has appeared in the Journal of International Business Studies, the Journal of Political Economy, the Journal of Economic Geography and the Strategic Management Journal among many others.

Lee Li is a Professor of Marketing at the Schulich School of Business at York University, Canada. His research is centered around internationalization processes, with a focus on high-tech firms and partnership strategies. His work has appeared in the Journal of International Business Studies and the Strategic Management Journal, among others.

Xufei Ma is an associate professor in the Department of Management at the Chinese University of
Hong Kong (CUHK) Business School. His research interests lie in corporate and international strategy, with a focus on emerging economies. His work has appeared in Journal of International Business Studies, the Strategic Management Journal, and the Academy of Management Journal, among others.

Shige Makino is a Professor of Management at the Chinese University of Hong Kong (CUHK) Business School. He is especially interested in exploring noneconomic based motivations on economic activities and their performance consequences in international business. His research has appeared in a number of leading journals, including the Journal of International Business Studies, the Academy of Management Journal, the Strategic Management Journal and Organization Science.

Gongming Qian is an associate professor in the Department of Management at the Chinese University of Hong Kong (CUHK) Business School. His research interests include the financial economics of multinational enterprises, foreign direct investment, international strategy, and entrepreneurship. His work has appeared in the Journal of International Business Studies and the Strategic Management Journal, among others.

Ron Boschma is Professor in Regional Economics in the Faculty of Geosciences at the University of Utrecht. His research interests lie in evolutionary economic geography, the spatial evolution of industries and the geography of innovation. His work has appeared in the Journal of Economic Geography, Research Policy, and the Annals of Regional Science, among many others. 